\title{
Seasonal variation and size distribution in the airborne indoor microbial concentration of residential houses in Delhi and its impact on health
}

\author{
Pradeep Kumar $\cdot$ A. B. Singh $\cdot$ Rajeev Singh $(\mathbb{D}$
}

Received: 19 October 2020/ Accepted: 21 June 2021 / Published online: 3 July 2021

(C) The Author(s), under exclusive licence to Springer Nature B.V. 2021

\begin{abstract}
Exposure of microbial agents in the air of indoor dwellings is associated with effects on respiratory and general health. The current study was conducted in the urban area of Delhi Metropolis for the seasonal quantitative assessment of viable microbial indoor air quality. Bioaerosol measurement was conducted by using Anderson six stage impactor with cut-off diameters of $7.0,4.7,3.3,2.1,1.1$, and $0.65 \mu \mathrm{m}$ ) throughout the all the seasons (April 2019 to March 2020). Meteorological parameters such as temperature and relative humidity were measured to check their effect on microbial survival. Air quality index data of the sampling area were recorded by DPCC air quality monitoring system, Ashok Vihar, Delhi. The highest $\left(1654 \pm 876.87 \mathrm{CFU} / \mathrm{m}^{3}\right)$ and lowest $\left(738 \pm 443.59 \mathrm{CFU} / \mathrm{m}^{3}\right)$ mean bacterial concentration in houses was recorded in August and December, respectively. Similarly, the highest fungal concentration $\left(1275 \pm 645.22 \mathrm{CFU} / \mathrm{m}^{3}\right)$ was found in
\end{abstract}

Supplementary Information The online version contains supplementary material available at https://doi.org/10.1007/ s10453-021-09718-3.

P. Kumar $\cdot$ R. Singh $(\bowtie)$

Department of Environmental Studies, Satyawati College, University of Delhi, Delhi, India

e-mail: 10rsingh@gmail.com

\section{A. B. Singh}

CSIR- Institute of Genomics and Integrative Biology

(IGIB), Delhi University Campus, Delhi, India
August and the lowest in $\left(776 \pm 462.46 \mathrm{CFU} / \mathrm{m}^{3}\right)$ in January. Bacterial respirable fraction shows an irregular pattern in different seasons. In the case of fungi, the respirable fraction of 2.1 and 1.1 contributes more than $60 \%$ of total culturable bioaerosols in all seasons. Bacterial genera including Staphylococcus, Micrococcus, and Streptobacillus were most dominant, and Cladosporium, Aspergillus, Penicillium, and Alternaria were the most dominant fungal genera observed indoors. The results of this study suggest that higher respirable fungal fraction might penetrate deeper into the lungs and cause various health effects. A higher concentration of bioaerosols in outdoor areas than indoor shows that the source of indoor bioaerosols is outdoor air.

Keywords Indoor air quality $\cdot$ Bioaerosols $\cdot$ Size distribution $\cdot$ Bacteria $\cdot$ Fungi

\section{Introduction}

The presence of bioaerosols (bacteria, fungi, viruses) in indoor air environments may act as the source of contamination. Colonization of bioaerosols may result in the form of infectious diseases, allergies, other toxic effects, and cancers (Srikanth et al., 2008). High levels of airborne microorganisms also causes respiratory infections, immunomodulatory reactions, and skin 
Table 2 Possible health effects of major bacteria and fungi isolated from indoor air

\begin{tabular}{|c|c|c|}
\hline $\begin{array}{l}\text { Microbial } \\
\text { Genera }\end{array}$ & Health effects & Reference \\
\hline \multicolumn{3}{|l|}{ Bacteria } \\
\hline Staphylococcus & Staphylococcal pneumonia, opportunistic infections & Srikanth et al, (2008) \\
\hline Micrococcus & $\begin{array}{l}\text { Pneumonia, Septic arthritis, endocarditis, bacteremia and } \\
\text { meningitis }\end{array}$ & Srikanth et al, (2008) \\
\hline \multicolumn{3}{|l|}{ Fungi } \\
\hline Aspergillus & $\begin{array}{l}\text { Respiratory infections, Aspergillosis } \\
\text { Asthma, Skin Infection, Sinus infection }\end{array}$ & $\begin{array}{l}\text { Baxi et al., (2016); Khan and Karuppayil (2012); } \\
\text { Inal et al., (2007); }\end{array}$ \\
\hline Alternaria & $\begin{array}{l}\text { Allergic diseases, Allergic Rhinitis, Skin infection, } \\
\text { Conjunctivitis }\end{array}$ & Husman (1996) \\
\hline Penicillium & $\begin{array}{l}\text { Lung infection, Hypersensitivity pneumonitis, Allergic } \\
\text { diseases, Allergic respiratory diseases }\end{array}$ & $\begin{array}{l}\text { Halonen et al., (1997) Baxi et al., (2016), Khan } \\
\text { and Karuppayil (2012) }\end{array}$ \\
\hline Candida & $\begin{array}{l}\text { Skin infection, Urinary tract infection, Digestive issues, Sinus } \\
\text { infection }\end{array}$ & Husman (1996) \\
\hline Mucor & $\begin{array}{l}\text { Allergic diseases, Allergic Rhinitis, Skin infection, } \\
\text { Conjunctivitis }\end{array}$ & Baxi et al., (2016) \\
\hline Cladosporium & Asthmatic reactions in children & Baxi et al., (2016) \\
\hline
\end{tabular}

problems (Baxi et al., 2016; Khan and Karuppayil 2012; Inal et al., 2007). High levels of bioaerosols in dwellings are also responsible for poor indoor air quality.

Exposure to poor indoor air quality has more often affect than outdoor air because almost $90 \%$ of people's time is spent in indoor environments (Bragoszewska et al., 2018). Poor living environment and hygiene is among major factors responsible for Sick building syndrome (SBS) (Herr et al., 2003). Localities near industrial areas are more likely to suffer from health issues than commercial and residential areas. A pilot questionnaire study conducted in Finland on 11,154 employees demonstrated that runny, stuffy or irritated nose, itching, burning, or irritation of eyes and fatigue are the most prevalent health problems (Reijula et al., 2004). Significant alteration in the concentration of $\mathrm{CO}$, PM, formaldehyde, and TVOC may also trigger health problems among students and staff in college (Wu et al., 2018). Housing/Overcrowding is also found to cause health issues related to the eye, ear, skin, respiratory system, and gastrointestinal tract (Melody et al., 2016). Animals, plants insects, and mites can produce biological allergens such as house dust, pets, and mold in indoor areas can trigger various allergic reactions and may be responsible for respiratory problems (WHO, 1988). Poor indoor air quality is also related to several health risks in waste pickers (Wikuats et al., 2020).

Many experimental and epidemiological studies also demonstrated that bioaerosol and pollen concentration is also responsible for health symptoms such as allergy, asthma, bronchitis, laryngitis, and sneezing, etc. are associated to indoor environments (Srikanth et al., 2008) Concentration of bioaerosols may vary from few colony-forming units (CFU) in the normal residential area to millions $\left(10^{9}\right) \mathrm{CFU} / \mathrm{m}^{3}$ locality near to dumping site. Abundance, diversity, viability, and community of bioaerosols may vary according to season and other meteorological parameters such as temperature, relative humidity, and wind speed (Frankel et al., 2012; Park et al., 2016). Fractions of airborne fungi such as Aspergillus, Curvularia, and Fusarium are more involved in triggering respiratory allergy and bronchial asthma than bacteria (Dey et al., 2019). Respirable fractions of bioaerosol with a size $(<2.5 \mu \mathrm{m})$ are able to penetrate deeper into the lungs (Humbal et al., 2019). Opportunistic pathogens and allergens are the major proportion of microflora found in residential houses (Sidra et al., 2015).

Various studies have been conducted throughout the World to assess microbial concentration in other indoor sites such as schools, colleges, hospitals, and public libraries or; but less attention was paid to residential houses (Madhwal et al., 2020; Frankel 
et al., 2012; Kumari et al., 2016; Park et al., 2016; Madamarandawala et al., 2019; Karmakar et al., 2020). Few studies have been conducted in Delhi to assess the bioaerosols concentrations in indoor environments (Gupta et al., 1993; Sharma, 2011). Total cultured colony-forming units $\left(\mathrm{CFU} / \mathrm{m}^{3}\right)$ and total fungi on slides were higher in (1989-90) than (1990-91) however, the pattern of concentration of different fungi was similar to the current study (Gupta et al., 1993). Different concentration of fungal aerosols was recorded in Delhi by Sharma and coworkers which reported $(110,091)$ and $(107,070)$ fungal colonies in per cubic meter area in indoor and outdoor area, respectively (Sharma et al., 2011). Bacterial sampling conducted in a slum area near Jawaharlal Nehru University (South Delhi) reported the high number of bacterial aerosols ranging from $0.43-3.35 \times 10^{7} \mathrm{CFU} / \mathrm{m} 3$, which is significantly higher than other similar studies (Kumar et al., 2013). Another study performed in JNU libraries recorded total bioaerosols within the range of 911-1460 CFU/m $\mathrm{m}^{3}$ and 2550-3110 CFU/m3 for bacteria and fungi, respectively (Ghosh et al., 2013). Ambient bioaerosol concentration measured between $\left(1740-3224 \mathrm{CFU} / \mathrm{m}^{3}\right)$ for fungi and (1990-9428 CFU/m ${ }^{3}$ ) in case of bacteria in different areas of Delhi. In general, this study also observed that most bioaerosols are found in stage $4(2.1-3.3 \mu \mathrm{m})$, stage $5(2.1-2.2 \mu \mathrm{m})$, these particles are capable of penetrating the lower parts of the lungs (Lal et al., 2017).

A study performed of the indoor environment in Pakistan reported significantly higher levels of bacteria $(275$ to 14,469$) \mathrm{CFU} / \mathrm{m}^{3}$ in living rooms however, the level of fungi was similar as per our study (Sidra et al., 2015). Studies performed in the indoor environments reported different levels of bacterial aerosols in a preschool in Poland showed (2205) $\mathrm{CFU} / \mathrm{m}^{3}$ in classrooms (Bragoszewska et al., 2018), and (3000) $\mathrm{CFU} / \mathrm{m}^{3}$ in an urban nursery school (Bragoszewska et al., 2015). Another study conducted by Park and coworkers showed a similar pattern of increase of bacterial concentration in different seasons (Park et al., 2016).

The objective of this study was to determine the pattern of abundance, diversity, and composition of microflora in different fractions and seasonal variation in the indoor air of residential houses.

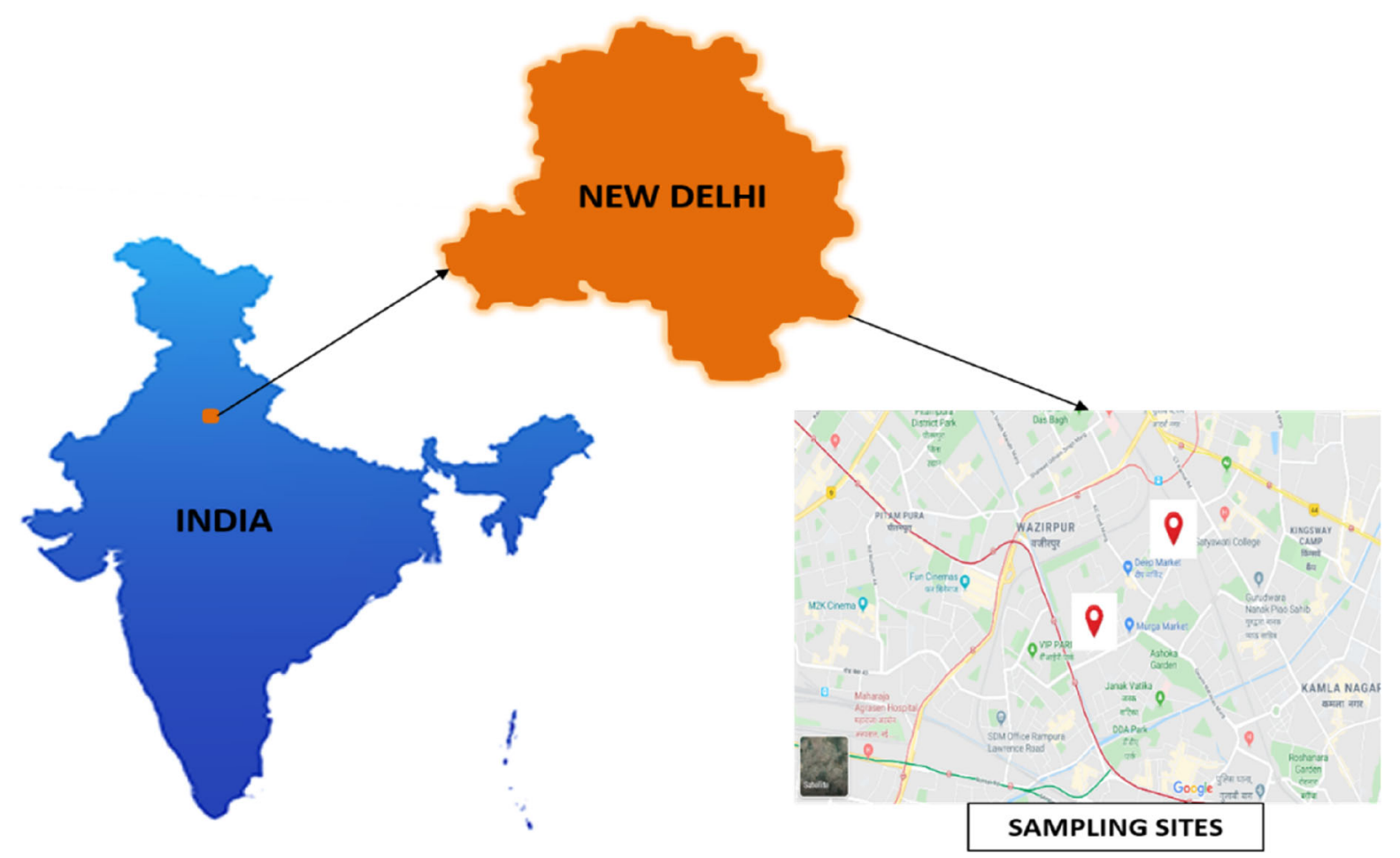

Fig. 1 Geographical description of biological sampling sites 


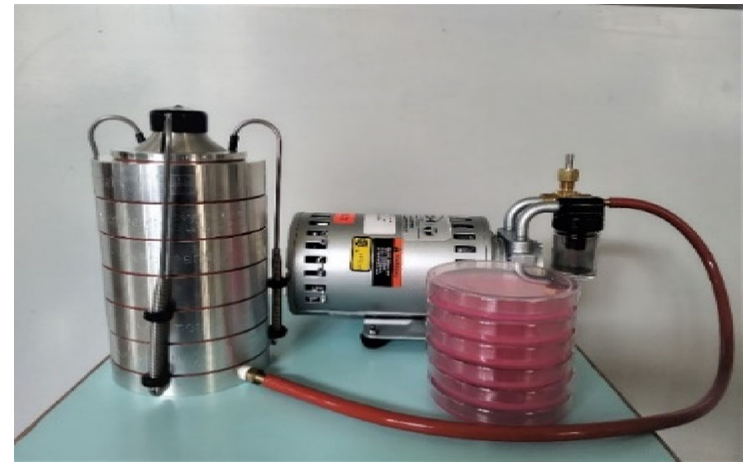

Fig. 2 Anderson Six stage Bioaerosol Impactor used for air sampling

\section{Materials and methods}

\subsection{Sites location and description}

The study was conducted in the selected areas of Delhi (North Delhi), which is India's national capital with a total area of $1,484 \mathrm{~km}^{2}$. The city is situated between $28^{\circ} 12^{\prime} 28^{\circ} 53^{\prime} \mathrm{N}$ and $76^{\circ} 50^{\prime} 77^{\circ} 23^{\prime} \mathrm{E}$ and is surrounded on both sides of the river Yamuna, flowing from north to south. Apart from the residential, commercial, and industrial area, it is also capitalized by Aravalli rocks hill range, forests, and trees on the roadside.

The study was carried out for one year (Apr 2019Mar 2020) aiming to check the effects of poor air quality on human health. Areas of North Delhi were selected because of the presence of mixed types of localities, e.g., residential areas including a slum area, Wazirpur industrial area, and commercial areas (Fig. 1). Municipal corporation of Delhi (MCD) Bhalsawa dumping ground is also in the range of 5 $\mathrm{KM}$ from location, which is responsible for toxic fumes, gases, and various microorganisms affecting air quality.

\subsection{Isolation, enumeration identification of bacteria}

Biological air sampling was conducted by using a calibrated Anderson Six Stage Impactor (Tisch Environmental, USA) having airflow of $28.3 \mathrm{l} / \mathrm{min}$ (Anderson A A 1958) Fig. 2. Six Petri dishes containing biological media were used in the sampler for a specific time and the sampler was operated at $1.5 \mathrm{M}$ (breathing height). Tryptic Soy Agar (Himedia USA) with Cycloheximide antifungal and Sabourd Dextrose agar supplemented with rose Bengal dye used as a nutrient medium for the growth of bacteria and fungi, respectively. Rose Bengal dye acted as an antibacterial agent and moreover, it maintains fungal colony morphology for a longer time. It was ensured that all the samples were collected in normal conditions and in triplicated form. One set of plates were exposed in outdoor spaces of houses, as controls to check the effect of ventilation, human activities, vegetation, etc. on microbial concentration.. According to the available data it is also clear that indoor spore concentration is affected by outdoor spores (Damialis et al., 2017). After exposure, agar plates were then sealed and transferred to the laboratory and incubated at $37{ }^{\circ} \mathrm{C}$ for 24-48 $\mathrm{h}$ in the case of bacteria while fungal colonies were incubated at $28.5^{\circ} \mathrm{C}$ for $7-14$ days. Colonies obtained were then counted and expressed as CFU/m3 and growth was recorded in form of colony-forming units (CFU) using colony counter.

Bioaerosol Concentration $\left(\mathrm{CFU} / \mathrm{m}^{3}\right)=$ No. of colonies/ (Flow rate $\times$ sampling duration (minutes).

After growth, bacteria were identified based on colony appearance, and morphological identification after gram staining. All bacteria were identified and characterized in groups such as gram-negative and gram-positive according to Bergey's manual of systematic microbiology (Bergey's manual). Biochemical characterization of the bacteria (catalase test, oxidase, indole test, etc.) was followed for further identification. The bacterial colonies which were most frequent were identified based on 16s RNA amplification by primers. Fungal colonies were initially identified on the basis of colony appearance, color, etc., then further by mounting them with the help of lactophenol cotton blue stain and under a high-power microscope (400-1000X). Macroscopic and microscopic procedures were performed according to (Sutton et al. 1997).

\subsection{Monitoring meteorological parameters}

Meteorological data were measured in indoor sites and as well as from Delhi pollution control center (DPCC) ambient air quality monitoring system, Satyawati College Ashok Vihar Station, 110052. Figure 1 shows the details of the study area and DPCC Center involved in the present study. Outdoor and indoor temperature $\left({ }^{\circ} \mathrm{C}\right)$, relative humidity $(\%)$, rainfall \& 
Fig. 3 Monthly variations in bacterial and fungal $\left(\mathrm{CFU} / \mathrm{m}^{3}\right)$ count in residential houses

Table 1 Major bacteria and fungi isolated from indoor air

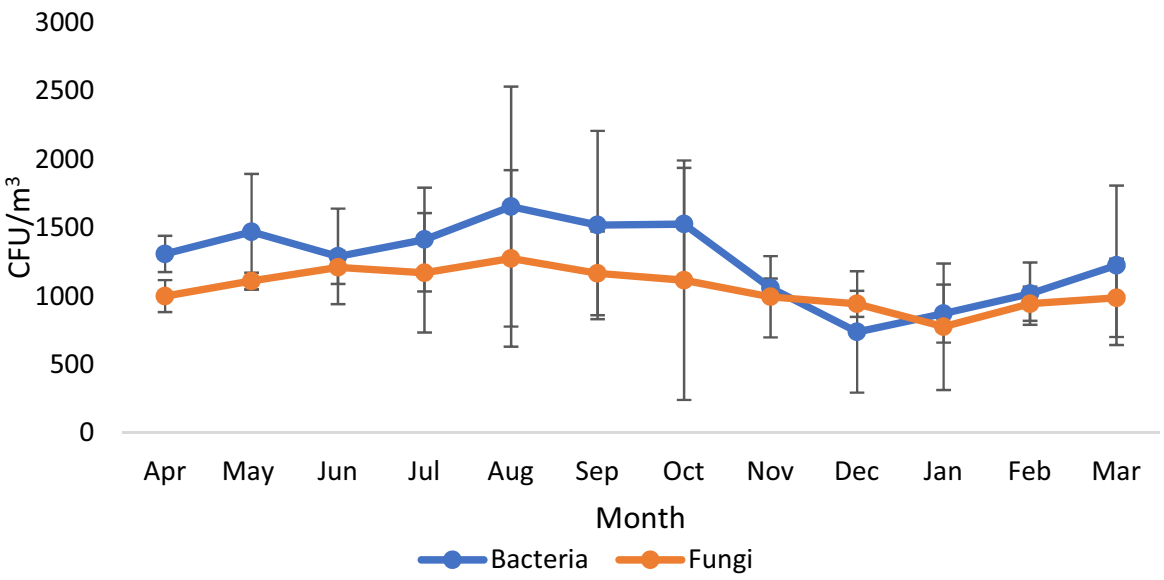

\begin{tabular}{ll}
\hline Major bacterial genera & Major Fungal genera \\
\hline Gram-positive cocci & Filamentous Fungi \\
$\mathrm{G}+$ Cocci & Alternaria \\
Micrococcus & Aspergillus \\
Staphylococcus & Aspergillus fumigatus \\
Streptococcus & A. niger \\
& A. flavus \\
Sporing gram-positive rods, family Bacillaceae & A. flavipies \\
& Cladosporium \\
Streptobacillus & Fusarium \\
Gram-negative rods, family Bacillaceae & Microsporum \\
E. coli & Mucor \\
G - Bacilli & Penicillium \\
Pseudomonas & Rhizopus \\
Gram-negative Spirillum, family Spirillaceae & Trichoderma \\
Spirillum & Yeasts \\
& Candida \\
\hline & Saccharomyces \\
\hline
\end{tabular}

wind speed were recorded and its relationship with aerospora was determined.

\subsection{Data analysis}

SPSS 22 and Microsoft excel 2019 were used for the statistical calculation. Single way ANOVA was used and variation in bacterial and fungal aerosols with different levels of temperatures and relative humidity odds ratio was also analyzed by using the same software. A statistical significance level of 0.05 was used throughout the study.

\section{Results and discussion}

3.1 Seasonal variation in total bioaerosol concentration in houses

Sampling time was divided into four seasons- winter (Dec-Feb), spring (Mar-May), summer (Jun-Aug), and fall (Sep-Nov). Concentration and types of indoor microorganisms are affected by residents and abiotic factors such as temperature, relative humidity, ventilation and cleaning frequency, etc. (Després et al., 2012). The presence of bioaerosols in the indoor environment is often related to several adverse effects 
on human health (WHO, 1988). As per reports of the World Health Organization (WHO), total microbial load should not exceed $1000 \mathrm{CFU} / \mathrm{m}^{3}$ in working and living area. Culturable seasonal concentrations of airborne bacteria and fungi is described in Fig. 3. The significant change was observed in bacterial concentration in different months $(\mathrm{p}>0.05)$. Levels of bacterial aerosols were ranged between $738 \pm 443.59-1654 \pm 876.87 \mathrm{CFU} / \mathrm{m}^{3}$; however, the level of fungi was $776 \pm 462.46-1275 \pm 645.22 \mathrm{CFU} / \mathrm{m}^{3}$ (Table 1). The concentration of bioaerosols outdoors fluctuated depending upon seasons, e.g., It was higher than indoor in summer and lower in the fall season. Starting from April 2018 with a mean of $1308 \mathrm{CFU} / \mathrm{m}^{3}$ reached its highest in August. The lowest bacterial concentration $\left(738 \pm 443.59 \mathrm{CFU} / \mathrm{m}^{3}\right)$ was recorded in December, which may be due to the lower temperature and lack of ventilation facility. The concentration of bacterial aerosols started increasing in June, probably due to high relative humidity in houses. The highest mean concentration was recorded in August in the same month that the highest relative humidity was recorded which may be the reason behind the high fungal activity. Similar to bacteria, the lowest fungal count was reported in winter (January month) which could be due to a lower temperature and less activity during this time. Seasonal measurement of airborne microbial concentration shows high abundance and variation of fungi in the summer and fall which may be probably due to high relative humidity. Human activities are mainly responsible for biological contamination in indoor areas (Hospodosky et al., 2012). A study conducted in Delhi Metropolis by Gupta and co-workers observed that Cladosporium is the most dominant culturable fungus followed by Ustilago and Aspergillus flavus. Concentrations of fungi were higher in April to July and lower in the dry and winter seasons (Gupta et al., 1993).

A similar study was conducted by Kumari and coworkers to measure the seasonal variation in the airborne fungi in swine houses. Ascomycota was the most dominant fungal phyla followed by Basidiomycota and Zygomycota. Diversity and abundance were higher in the summer season than in winters (Kumari et al., 2016). Karmakar et al., 2020 indicated in their study that primary indoor spaces have the Ascospore, basidiospore, Cladosporium, and Aspergilli group of fungi in high concentrations. The presence of nutrients and optimum temperature favors the occurrence and growth of different fungi in indoors (Karmakar et al., 2020). Significant variation was observed in the indoor bacterial and fungal concentrations in different seasons. Bacterial mean concentration peaked in the $2165 \mathrm{CFU} / \mathrm{m}^{3}$ in spring and least in summer $240 \mathrm{CFU} / \mathrm{m}^{3}$ however, fungi reach its maximum in houses in summers $235 \mathrm{CFU} / \mathrm{m}^{3}$ and lowest in winters $26 \mathrm{CFU} / \mathrm{m}^{3}$ (Frankel et al., 2012). Unlike this study, current data shows the highest bacterial concentration at the start of the fall season (August) and the lowest in the winter however fungal abundance the follow the same pattern (Frankel et al., 2012). (Madhwal et al., 2020) monitored the bioaerosols near Bus station and an almost similar trend was recorded in all the seasons. Aspergillus, Penicillium, and Cladosporium were the most dominant fungi; however, Micrococcus, Staphylococcus, and Bacillus were the most dominant bacterial genera (Madhwal et al., 2020), and the same results were shown in the monitoring of indoor air of pharmacy (Jankowiak et al., 2020). Fungal aerosols started declining from July-August, which may be due to increased soil moisture and hence, decreased resuspension of fungi in these months (Fan et al., 2017; Rathnayake et al., 2017). A recent Chinese study performed by $\mathrm{Li}$ and co-workers reported interesting variation in the indoor microflora in male and female dormitories, according to data Female microenvironments have higher bacterial aerosols than females ( $\mathrm{Li}$ et al., 2020).

\subsection{Size distribution of bioaerosols in different seasons}

Measurement of culturable bioaerosols in the indoor air of residential houses was collected in different stages of air sampler. Isolation and characterization of bioaerosols of different sizes were conducted for the reason that different sizes of the airborne particles are able to penetrate in different levels of the human respiratory system. According to Anderson, the particles of $7 \mu \mathrm{m}$ or above (1st stage) will stick on preseparator, 4.7-7.0 $\mu \mathrm{m}$ (2nd stage) in the pharynx, 3.3-4.7 (3rd stage) in the trachea and primary bronchi, 3.3-2.1(4th stage) $\mu \mathrm{m}$ in secondary bronchi, 2.1-1.1 $\mu \mathrm{m}$ (5th stage) in terminal bronchi, and $1.1-0.65 \mu \mathrm{m}$ (6th stage) will reach up to alveoli of lungs (Anderson, 1958; Sturm R, 2016). The size distribution observed in all four seasons was 
Fig. 4 Seasonal size distribution for bacterial aerosols in indoor air
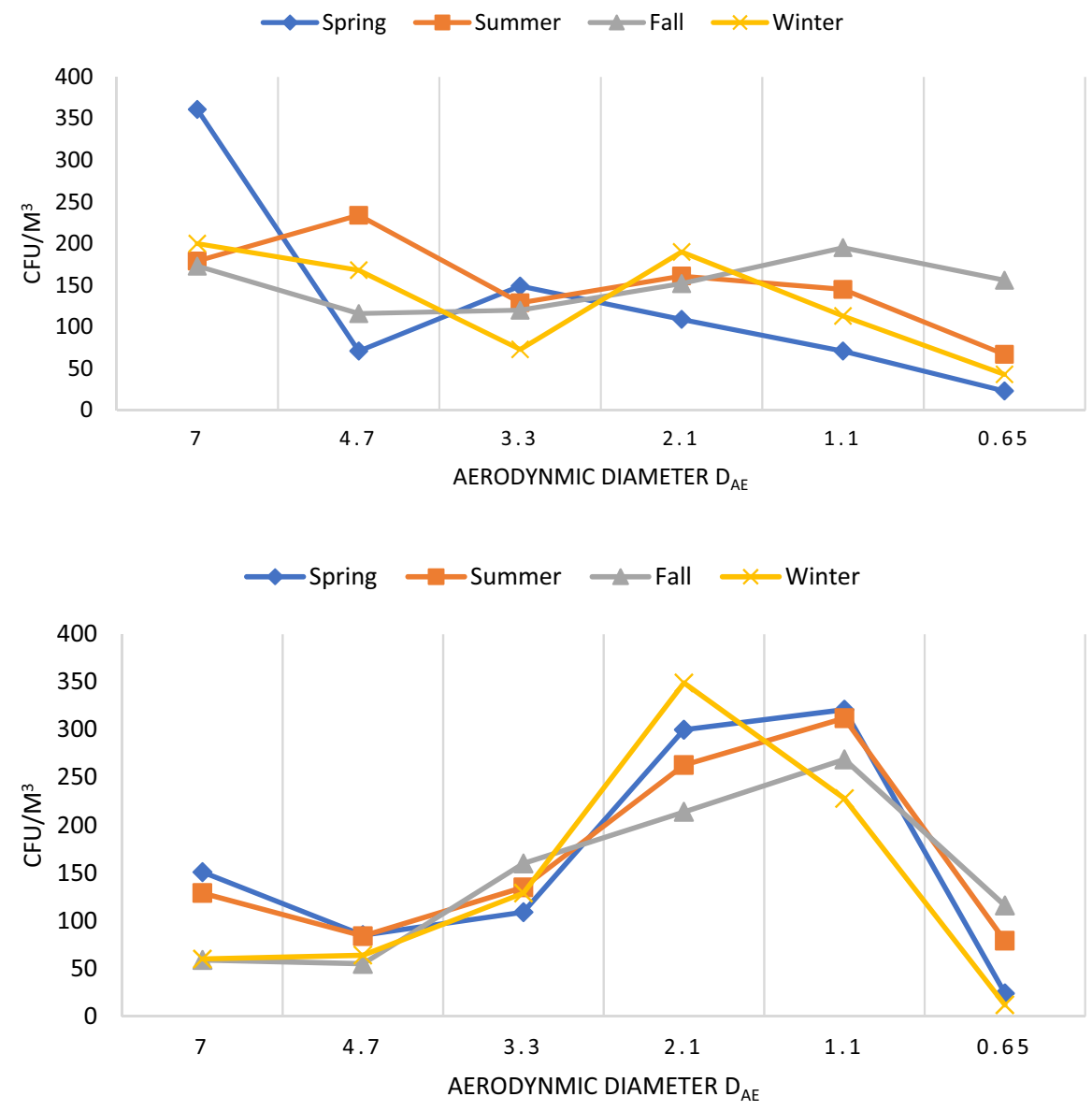

Fig. 5 Seasonal size distribution for fungal aersols in indoor air
In the case of fungi, a different pattern was recorded in diameter size ( $p>0.05)$ (Fig. 5). Data shows that smaller fungal particles $>2.5 \mu \mathrm{m}$ were most dominant in all seasons. These smaller particles may deposit in the lower tracheal or alveolar region of the lungs and cause various problems among human beings. In winter, the fungal aerosols ranging $2.1 \mu \mathrm{m}$ were most dominant than other size particles. The absence of smaller particles in winter could be probably due to the aggregation of fungal aerosols with non-biological particles. A similar pattern was recorded in the distribution of fungal aerosols in spring and summer with the most dominant particles in 2.1 and $1.1 \mu \mathrm{m}$. The rainy season shows a different pattern than other seasons, course particles $>7 \mu \mathrm{m}$ were minimum like winter season however, fine fungal particles were more prevalent than in any other season. Lal and co-workers reported the highest fungal aerosols in the $3^{\text {rd }}$ stage $(3.3-4.7 \mu \mathrm{m})$ and $4^{\text {th }}$ stage 
(3.3-2.1 $\mu \mathrm{m})$ of the Anderson air sampler from different sites in Delhi (Lal et al., 2017).

Normally microorganisms are associated with the particulate matter present in our ambient atmosphere in form of bioaerosols but they have also the ability to float freely in the air. According to our data bacterial population is higher than fungi in total concentration and as well as submicron fractions. Human and anthropogenic activities can induce the dust formation and aerosolization process and can also affect the human respiratory system (Madwal et al., 2020; Johnson et al., 2011).

\subsection{Identification of culturable bioaerosols}

After successfully sampling and culturing viable fungal and bacterial aerosols, identification procedures were performed. In the case of bacteria, isolated
Fig. 6 Common isolated fungal and bacterial aerosols (a. Streptobacillus; b. Micrococcus; c. Bacillus; d. Aspergillus fumigatus; e. Alternaria; f. Rhizomucor; g. Rhizopus; h. Penicillium; i. Microsporum; j. A. niger) (Sutton et al., 1997)

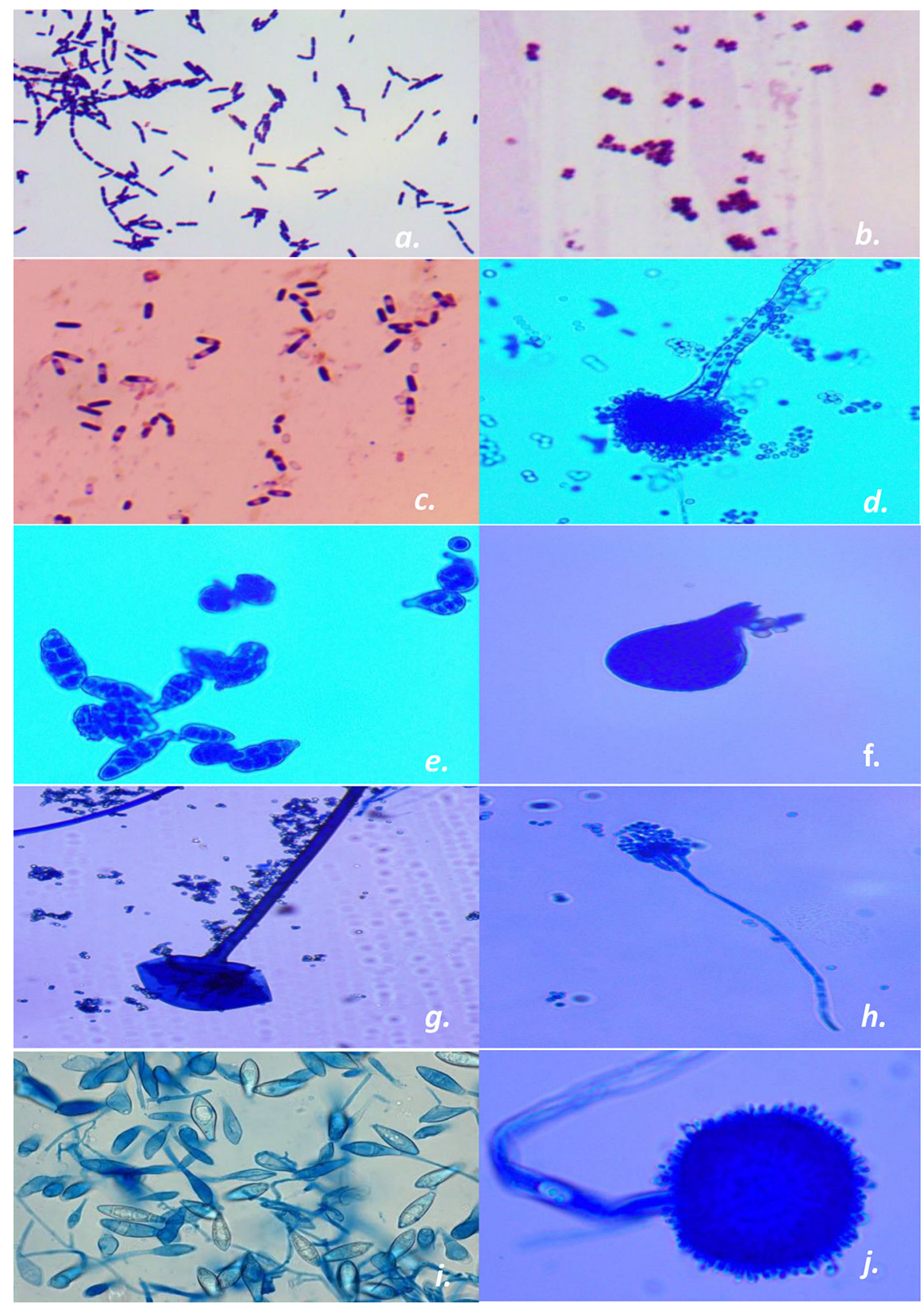


samples were identified on basis of macrobiological and microbiological features such as colony morphology, gram staining, cell morphology, etc., and compared according to Bergey's Manual of Systematic bacteriology. Fungi were initially identified on the basis of colony color, shape, spores, and pattern and later on, lactophenol cotton stain was used for mounting and identification of fungi as suggested by (Sutton et al., 1997). Although exact species-level identification of fungi is not possible on the primary level, however several efforts have been done to achieve this. Fungal species were identified on the basis colony characteristics and spore formation. In this context, pure cultures of the prominent isolated fungal genera were prepared and preserved at lower temperatures. Moreover, stored isolated (experimental) fungal tubes were compared with reference tubes of fungal species taken from the Indian agricultural research institute (IARI) Delhi and standard manuals. Fungal spores were also identified on basis of morphology through The British aerobiological federation 1995, and another important study by Campwell et al. (2013). Confirmation of conidia of Aspergillus and Penicillium group was conducted with the help of the culture methods (Oliveira et al., 2009). SARS-CoV-2 (COVID-19) also transmits via person-to-person contact through bioaerosols thus, there is an urgent need for research to calculate the relation of infected particles with aerosols. Photomicrographs of the bacterial and fungal agents are also given (Fig. 6) moreover, morphological features of isolated cultured bioaerosols were compared with standard manual (Sutton et al., 1997; Bergey's Manual of Systematic Bacteriology; Campwell et al., 2013).

Dominant airborne bacterial and fungal genera that were observed by culture methods are described in Table 1. A similar observation held by (Aydogdu et al., 2010) reported more $\mathrm{G}+$ Cocci than G-bacilli in childcare centers. The quality and quantity of indoor air microflora of the hospitals is important for the health workers, staff and patients. Cladosporium (47\%), Aspergillus (17\%), Penicillium, (7\%), etc., and Staphylococcus, Micrococcus, Kocuria, Aerococcus, Kytococcus, etc. were the most dominant fungal and bacterial genera, respectively, in hospital (Asif et al., 2018). According to the previous data, the occurrence of common fungal genera Aspergillus and Penicillium are through waste products such as puss, fluid, cotton, and tissues (Motta et al., 2018). Bacterial genera identified in the current study belong to opportunistic pathogens and may act as a risk factors for respiratory health. The presence of Pseudomonas and few other bacteria in indoor sites can cause disease in preschool children (Madamarandawala et al., 2020).

\subsection{Seasonal composition of bioaerosols}

\subsubsection{Fungal genera and their possible effects on human health}

The proportion of isolated fungi up to genus -level from the indoor area is described in (Fig. 7a). Cladosporium (26\%), Aspergillus spp. (23\%). and Penicillium spp. (19\%) were the most prevalent fungal genera in houses. However, other molds such as Candida, Rhizopus, Fusarium, Trichoderma, Microsporum, Yeast, etc. (Fig. 7b). were also reported in the lower proportion. The relative abundance of the fungal aerosols in different seasons is provided as supplementary material (Supplementary file). We also calculated the concentration of top indoor fungal genera which are most significant for human health was identified in CFU $/ \mathrm{m}^{3}$ in different seasons (Fig. 8). Cladosporium was most prevalent in the fall and summer however, Penicillium was most dominant in the winter and spring season. It can also be observed that Aspergillus is more dominant in spring than in other seasons. A similar pattern was observed by (Madhwal et al., 2020) where Aspergillus and Penicillium were most dominant in summer. Airborne fungal abundance and diversity in hospitals of Delhi have shown higher concentrations of Cladosporium, Aspergillus and Fusarium followed by other fungi. (Singh et al., 1994). Airborne fungi can induce allergic reactions in human beings (Husman 1996; Khan and Karuppayil 2012; Baxi et al., 2016). Alternaria, Cladosporium, Penicillium, Aspergillus, and Mucor are major indoor fungal genera responsible for allergic reactions (Halonen et al., 1997; Husman 1996; Inal et al., 2007; Khan and Karuppayil 2012; Baxi et al., 2016) (Table 2). As per current data and these studies about the health effects of airborne fungi, it can be deduced that the high concentration of allergenic fungi might be related to adverse respiratory health problems. A recent study conducted by Karmakar and coworkers reported that Aspergillus has shown the highest proportion as an allergenic candidate in skin prick test (SPT) in asthmatic and non-asthmatic 
Fig. 7 a. Proportion of fungi isolated from residential houses $\mathbf{b}$. Airborne fungi growing on SDA agar medium with rose Bengal dye a

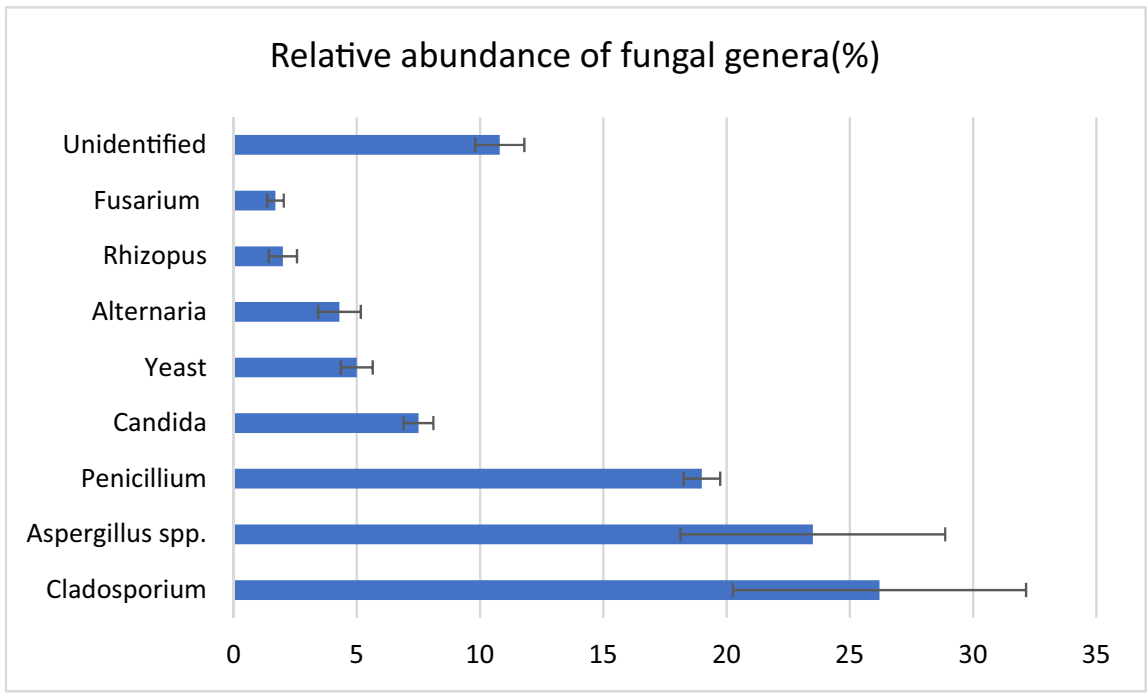

b

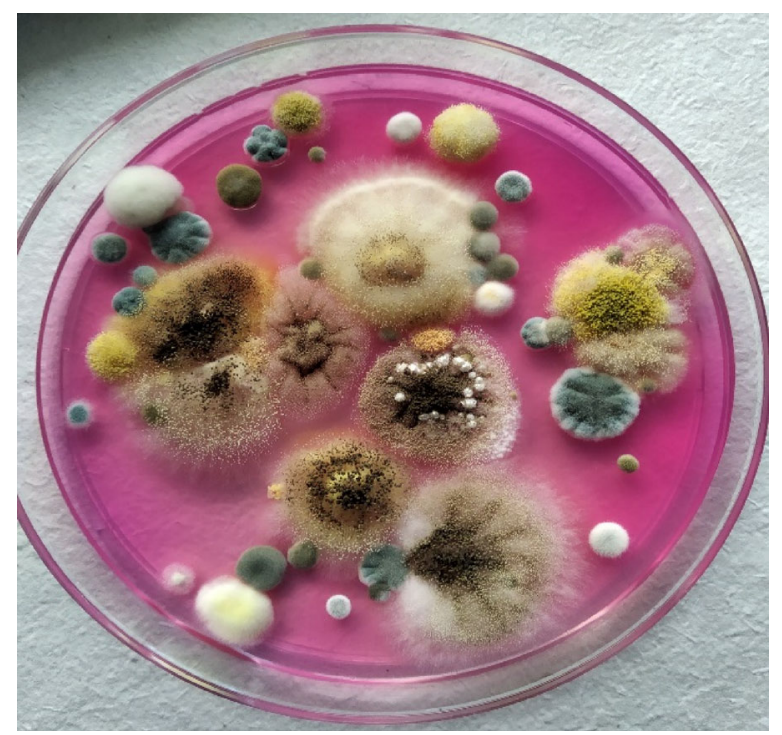

patients (Karmakar et al., 2020). Another SPT-based study from northern India performed on asthma and allergic rhinitis suggested that A. flavus, A. fumigatus, and Penicillium are major allergens (Mehta et al., 2018).

3.5 Meteorological factors affecting temporal variation in bioaerosol concentration

Figure 8 shows the variation in meteorological parameters during sampling time. Mean indoor temperature ranged from $17.6{ }^{\circ} \mathrm{C}$ in January to $34.6{ }^{\circ} \mathrm{C}$ in June however, outdoor temperature was between 16.3-33 ${ }^{\circ} \mathrm{C}$ (Fig. 9). Lower temperature and lack of ventilation facilities are major factors responsible for the decrease in the concentration of bioaerosols. The optimum temperature for mesophilic bacteria is around $37{ }^{\circ} \mathrm{C}$ and however, fungi grow as a relatively lower temperature and higher relative humidity than bacteria. Air quality index (AQI) is also an important factor responsible for the health and comfort of residents in indoor air (Fig. 10). Data shows the peak in AQI at 
around 350 which falls under the "hazardous" category as per standards by the Environmental protection agency (EPA). The hazardous category is an emergency and health warning with the probability of effects on the whole population (Air Quality Index EPA 2020). A study conducted by Frankel and coworkers that microbial occurrence suggested that temperature, relative humidity, and air exchange rates significantly affect the microbial concentration (Frankel et al., 2012). Association of particulate matter (PM) with bioaerosols directly influences the infectibility, survival, and of air microorganisms in the atmosphere. Vehicular movement is also one of the important factors influencing the PM in the ambient air (Sundriyal et al., 2018). Smaller particles can persist for a long time in the air and are more likely to penetrate deeper parts of the respiratory system (Fang et al., 2008; Zukiewicz-Sobczak, 2013). A study by Johnson and co-workers suggested that persons who came within the range of $1 \mathrm{M}$ with infected patients were infected by severe acute respiratory syndrome (SARS) (Johnson et al., 2011).

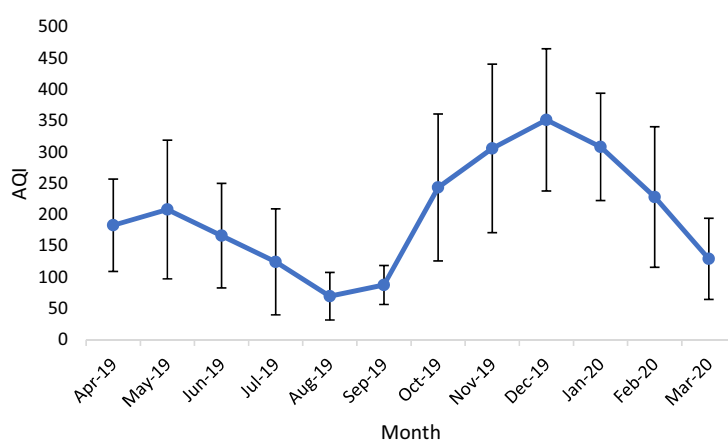

Fig. 10 Mean air quality index (AQI) in month of sampling (Determined by Delhi pollution control center (DPCC) Ambient Air quality monitoring system, Satyawati College Ashok Vihar Station, Delhi)

Fig. 8 Seasonal variation in predominant fungi

\section{Metrological parameters during sampling time}

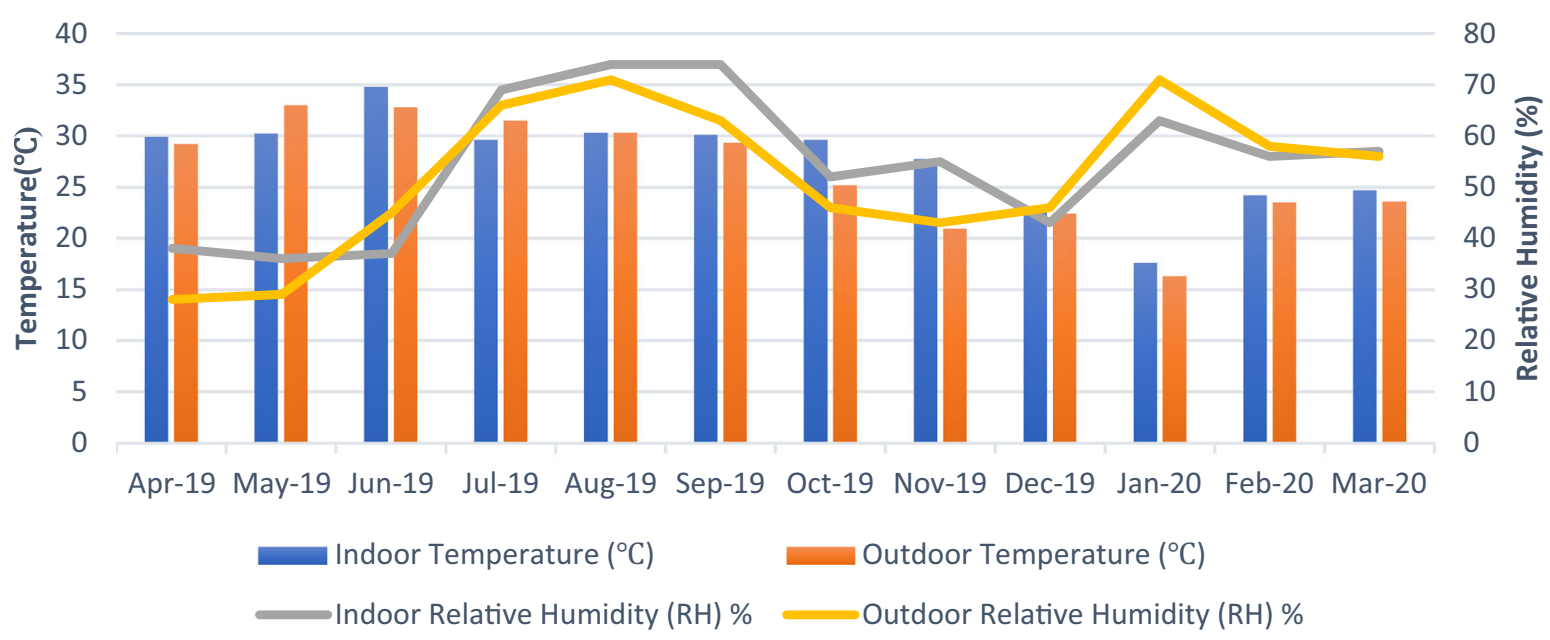

Fig. 9 Mean value of the metrological parameters (Temperature, relative humidity) affecting bioaerosol concentration in indoor area 


\section{Conclusion}

The outcome of the study suggests that microbial concentration is influenced by seasonal variation. Indoor air bacterial and fungal concentration was significantly higher in summer and fall than in other seasons. The abundance, composition, and diversity of Bioaerosols are also influenced by other factors such as ventilation and human activity. The higher outdoor concentration of bacteria and fungi shows that these are mainly occurred from outdoor to indoor. Data also indicate that fungal aerosols are the highest concentration in cut-off diameter $2.1-1.1 \mu \mathrm{m}$ in all seasons, which points out its possible association with respiratory problems. The presence of Aspergillus, Penicillium, Cladosporium, Alternaria, etc. in high concentrations in indoor dwellings supports this fact. Overall, this study will help in understanding the diversity, abundance, and community composition of the microbial agents in indoor air.

Acknowledgements This work was financially supported by Science and Engineering Research Board, Department of Science and Technology (SERB-DST), New Delhi, India.

Authors contribution $\mathrm{P} \mathrm{K}$ performed the experiments and wrote the manuscript. A B S drafted and edited the manuscript. R S designed, analyzed and supervised the study.

\section{Declaration}

Conflict of interest The authors declare that they have no conflict of interest.

\section{References}

Air Quality Index (AQI) basics.(2020) (EPA) AirNow. Available at: https://cfpub.epa.gov/airnow/index.cfm?action= aqibasics.aqi Accessed on: October 172020

Andersen, A. A. (1958). New sampler for the collection, sizing, and enumeration of viable airborne particles. Journal of Bacteriology, 76(5), 471-484. https://doi.org/10.1128/JB. 76.5.471-484.1958

Asif, A., Zeeshan, M., Hashmi, I., Zahid, U., \& Bhatti, M. F. (2018). Microbial quality assessment of indoor air in a large hospital building during winter and spring seasons. Building and Environment, 135, 68-73.

Aydogdu, H., Asan, A., \& Tatman, O. M. (2010). Indoor and outdoor airborne bacteria in child day-care centers in Edirne City (Turkey), seasonal distribution and influence of meteorological factors. Environmenatal Monitor Assessment. https://doi.org/10.1007/s10661-009-0874-0
Baxi, S. N., Portnoy, J. M., Larenas-Linnemann, D., \& Phipatanakul, W. (2016). Exposure and health effects of fungi on humans. The Journal of Allergy and Clinical Immunology, 4(3), 396-404.

Brągoszewska, E., \& Biedroń, I. (2018). Indoor air quality and potential health risk impacts of exposure to antibiotic resistant bacteria in an office rooms in Southern Poland. International Journal of Environmental Research and Public Health, 15(11), 2604. https://doi.org/10.3390/ ijerph15112604

Brągoszewska, E., Mainka, A., Pastuszka, J. S., Lizończyk, K., \& Desta, Y. G. (2018). Assessment of bacterial aerosol in a preschool, primary school and high school in Poland. Atmosphere, 9, 87.

Campwell, C. K., Johnson, E. M., \& Warnock, D. W. (2013) Identification of Pathogenic Fungi. 2nd Edn., Online ISBN:9781118520055. https://doi.org/10.1002/ 9781118520055

Damialis, A., Kaimakamis, E., Konoglou, M., et al. (2017). Estimating the abundance of airborne pollen and fungal spores at variable elevations using an aircraft: how high can they fly? Science and Reports, 7, 44535. https://doi.org/10. 1038/srep44535

Després, V. R., Alex Huffman, J., Burrows, S. M., Hoose, C., Safatov, A. S., Buryak, G., et al. (2012). Primary biological aerosol particles in the atmosphere: a review. Tellus Series B: Chemical and Physical Meteorology, 64(1), 15598.

Dey, D., Ghosal, K., \& Bhattacharya, S. G. (2019). Aerial fungal spectrum of Kolkata, India, along with their allergenic impact on the public health: A quantitative and qualitative evaluation. Aerobiologia, 35, 15-25. https://doi.org/10. 1007/s10453-018-9534-6

Ewa, B., Mainka, A., \& Pastuszka, J. S. (2015). Bacterial aerosols in an urban nursery school in Gliwice, Poland: a case study. Aerobiologia. https://doi.org/10.1007/s10453015-9419-x

Fan, H., Li, X., Deng, J., Da, G., Gehin, E., \& Yao, M. (2017). Time-dependent size-resolved bacterial and fungal aerosols in Beijing subway. Aerosol and Air Quality Research, 17, 799-809. https://doi.org/10.4209/aaqr.2016.03.0114

Fang, Z., Ouyang, Z., Zheng, H., \& Wang, X. (2008). Concentration and size distribution of culturable airborne microorganisms in outdoor environments in Beijing, China. Aerosol Science and Technology. https://doi.org/10. 1080/02786820802068657

Frankel, M., Bekö, G., Timm, M., Gustavsen, S., Hansen, E. W., \& Anne Mette, M. (2012). Seasonal variations of indoor microbial exposures and their relation to temperature, relative humidity and air exchange rate. Applied and Environmental Microbiolog, 78(23), 8289-8297.

Ghosh, B., Lal, H., Kushwaha, R., et al. (2013). Estimation of bioaerosol in indoor environment in the university library of Delhi. Sustain Environ Res, 23, 199-207.

Grzyb, J., \& Lenart-Boroń, A. (2019). Bacterial bioaerosol concentration and size distribution in the selected animal premises in a zoological garden. Aerobiologia, 35, 253-268. https://doi.org/10.1007/s10453-018-09557-9

Gupta, S., Pereira, B., \& Singh, A. B. (1993). Survey of airborne culturable and non-culturable fungi at different sites in Delhi metropolis. Asian Pacific Journal of Allergy and Immunology, 11(1), 19-28. 
Halonen, M., Stern, D. A., Wright, A. L., Taussig, L. M., \& Martinez, F. D. (1997). Alternaria as a major allergen for asthma in children raised in a desert environment. American Journal of Respiratory and Critical Care Medicine, 155, 1356-1361.

Herr, C. E., Zur Nieden, A., Jankofsky, M., Stilianakis, N. I., Boedeker, R. H., \& Eikmann, T. F. (2003). Effects of bioaerosol polluted outdoor air on airways of residents: a cross sectional study. Occupational and Environmental Medicine, 60(5), 336-342. https://doi.org/10.1136/oem.60. 5.336

Hospodsky, D., Qian, J., Nazaroff, W. W., Yamamoto, N., Bibby, K., Rismani-Yazdi, H., \& Peccia, J. (2012). Human occupancy as a source of indoor airborne bacteria. PLoS ONE, 7, e34867. https://doi.org/10.1371/journal.pone. 0034867

Humbal, C., Joshi, S. K., Trivedi, U. K., et al. (2019). Evaluating the colonization and distribution of fungal and bacterial bio-aerosol in Rajkot, western India using multi-proxy approach. Air Quality, Atmosphere and Health, 12, 693-704. https://doi.org/10.1007/s11869-019-00689-6

Husman, T. (1996). Health effects of indoor-air microorganism. Scandinavian Journal of Work, Environment \& Health, 22(1), 5-13.

Inal, A., Karakoc, G. B., Altintas, D. U., Guvenmez, H. K., Aka, Y., Gelisken, R., Yilmaz, M., \& Kendirli, S. G. (2007). Effect of indoor mold concentrations on daily symptom severity of children with asthma and/or rhinitis monosensitized to molds. Journal of Asthma, 44(543-546), 26.

Jankowiak, E., Kubera, Ł, Małecka-Adamowicz, M., et al. (2020). Microbiological air quality in pharmacies and an antibiotic resistance profile of staphylococci species. Aerobiologia, 36, 551-563. https://doi.org/10.1007/s10453020-09651-x

Johnson, G. R., Morawska, L., Ristovski, Z. D., Hargreaves, M., Mengersen, K., Chao, C. Y. H., et al. (2011). Modality of human expired aerosol size distributions. Journal of Aerosol Science, 42(12), 839-851. https://doi.org/10.1016/ j.jaerosci.2011.07.009

Karmakar, B., SenGupta, K., Kaur, A., et al. (2020). Fungal bioaerosol in multiple micro-environments from eastern India: source, distribution, and health hazards. SN Applied Science, 2, 565. https://doi.org/10.1007/s42452-020-2323-1

Khan, H. A. A., \& Karuppayil, M. S. (2012). Fungal pollution of indoor environments and its management. Saudi Journal of Biological Science, 19(4), 405-426. https://doi.org/10. 1016/j.sjbs.2012.06.002

Kumar, B., Gupta, G., Singh, S. B., \& Kulshrestha, U. (2013). Study of Abundance and Characterization of Culturable Bioaerosol at Delhi India. International Journal of Environmental Engineering and Management., 4(3), 219-226.

Kumari, P., Woo, C., Yamamoto, N., et al. (2016). Variations in abundance, diversity and community composition of airborne fungi in swine houses across seasons. Science and Reports. https://doi.org/10.1038/srep37929

Lal, H., Ghosh, B., Srivastava, A., \& Srivastava, A. (2017). Identification and characterization of size-segregated bioaerosols at different sites in Delhi. Aerosol Air Quality Research, 17, 1570-1581. https://doi.org/10.4209/aaqr. 2015.05.0331
Li, Y., Ge, Y., Wu, C., et al. (2020). Assessment of culturable airborne bacteria of indoor environments in classrooms, dormitories and dining hall at university: a case study in China. Aerobiologia, 36, 313-324. https://doi.org/10.1007/ s10453-020-09633-z

Madamarandawala, P., Weerasinghe, Y., Pathiraja, D., et al. (2019). Impact of microbial air quality in preschools on paediatric respiratory health. SN Applied Science. https:// doi.org/10.1007/s42452-019-1306-6

Madhwal, S., Prabhu, V., Sundriyal, S., \& Shridhar, V. (2020). Ambient bioaerosol distribution and associated health risks at a high traffic density junction at Dehradun city, India. Environmental Monitoring and Assessment, 192(3), 196. https://doi.org/10.1007/s10661-020-8158-9.PMID: 32086610;PMCID:PMC7087893

Mehta, D., Dagar, A., Kishan, J., Singh, P., Nehra, T., \& Sharma, H. (2018). Common allergens prevalent in and around Ambala, Haryana: an intradermal study among patients with asthma and allergic rhinitis and atopic dermatitis. Indian Journal of Dermatology, 63(4), 311-316. https://doi.org/10.4103/ijd.IJD_438_17

Melody, S. M., Bennett, E., Clifford, H. D., Johnston, F. H., Shepherd, C. C., Alach, Z., Lester, M., Wood, L. J., Franklin, P., \& Zosky, G. R. (2016). A cross-sectional survey of environmental health in remote Aboriginal communities in Western Australia. International Journal Environmental Health Research. https://doi.org/10.1080/ 09603123.2016.1194384

Motta, O., Zarrella, I., Cucciniello, R., Capunzo, M., \& De Caro, F. (2018). A new strategy to control the proliferation of microorganisms in solid hospital waste and the diffusion of nosocomial infections. Le Infezioni in Medicina, 26(3), 210-215. PMID: 30246763.

Oliveira, M., Ribeiro, H., Delgado, J. L., et al. (2009). Seasonal and intradiurnal variation of allergenic fungal spores in urban and rural areas of the North of Portugal. Aerobiologia, 25, 85-98. https://doi.org/10.1007/s10453-009-9112-z

Park, J., Ichijo, T., Nasu, M., et al. (2016). Investigation of bacterial effects of Asian dust events through comparison with seasonal variability in outdoor airborne bacterial community. Science and Reports, 6, 35706. https://doi.org/ 10.1038/srep35706

Rathnayake, C. M., Metwali, N., Jayarathne, T., Kettler, J., Huang, Y., Thorne, P. S., \& Stone, E. A. (2017). Influence of rain on the abundance of bioaerosols in fine and coarse particles. Atmospheric Chemistry and Physics, 17(3), 2459-2475.

Reijula, K., \& Sundman-Digert, C. (2004). Assessment of indoor air problems at work with a questionnaire. Occupational and Environmental Medicine, 61(1), 33-38.

Sharma, R., et al. (2011). Indoor fungal concentration in the homes of allergic/asthmatic children in Delhi India. Allergy \& Rhinology (providence). https://doi.org/10.2500/ ar.2011.2.0005

Sidra, S., Ali, Z., Sultan, S., Ahmed, S., Colbeck, I., \& Nasir, Z. A. (2015). Assessment of airborne microflora in the indoor micro-environments of residential houses of Lahore, Pakistan. Aerosol Air Quality Research, 15, 2385-2396. https://doi.org/10.4209/aaqr.2014.12.0338 
Singh, A., Gangal, S. V., \& Singh, A. B. (1994). Airborne fungi in the hospitals of metropolitan Delhi. Aerobiologia, 10, 11-21. https://doi.org/10.1007/BF02066742

Srikanth, P., Sudharsanam, S., \& Steinberg, R. (2008). Bioaerosols in indoor environment: composition, health effects and analysis. Indian Journal Medical Microbiology. https://doi.org/10.4103/0255-0857.43555

Sundriyal, S., Shridhar, V., Madhwal, S., Pandey, K., \& Sharma, V. (2018). Impacts of tourism development on the physical environment of Mussoorie, a hill station in the lower Himalayan range of India. Journal of Mountain Science, 15(10), 2276-2291. https://doi.org/10.1007/s11629-0174786-0

Sutton DA,Fothergill AW. (1997) Guide to Clinically Significant Fungi Paperback - Import.

WHO. Indoor Air Quality: Biological Contaminants: Report on a Who Meeting, Rautavaara. Volume 31 World Health
Organization Regional Office for Europe; Copenhagen, Denmark: 1988.

Wikuats, C. F. H., Duarte, E. H., Prates, K. V. M. C., et al. (2020). Assessment of airborne particles and bioaerosols concentrations in a waste recycling environment in Brazil. Science and Reports, 10, 14812. https://doi.org/10.1038/ s41598-020-71787-0

Wu, Y., Lu, Y., \& Chou, D. C. (2018). Indoor air quality investigation of a university library based on field measurement and questionnaire survey. International Journal of Low-Carbon Technologies, 13(2), 148-160. https://doi. org/10.1093/ijlct/cty007

Zukiewicz-Sobczak, W. A. (2013). The role of fungi in allergic diseases. Postepy Dermatologii i Alergologii, 30(1), 42-45. https://doi.org/10.5114/pdia.2013.33377 